\title{
Chapter 15 \\ The Internationalization of Elite \\ Education. Merging Angles of Analysis and Building a Research Object
}

\author{
Anne-Catherine Wagner
}

Today the dominant classes are characterized by their mobility, the geographical spread of their networks of relations, and more generally by their belonging to a reference space that goes beyond the national framework. This transformation undeniably has effects on the formation of elites in different countries, which increasingly includes an international dimension (Maxwell 2018; van Zanten and Darchy-Koechlin 2015). How can we, as researchers, take into account the international dimension in the formation of elites?

We would like to show here both the theoretical relevance and the difficulties of an approach of international capital that focuses on its institutionalized state, comprised of officially sanctioned educational qualifications. The multiplicity of levels and training models displaying an international dimension, and the social heterogeneity of their public, complicate the construction of this object. Should we include all schools defining themselves as international in the field? The internationalization of education programs often takes the shape of study abroad periods rather than attendance at specific institutions; and stays abroad concern a growing number of students that are not all part of the elite. What would be the invariant features of an international educational capital? How and to what extent is it mobilized in the reproductive strategies of the ruling classes? In a context of relative democratization of international experiences, how do the dominant classes maximize their potential for distinction? Do all students benefit equally from an international education?

These questions will be dealt with by focusing more specifically on the case of France where, traditionally, attending a few highly selective institutions closely defines the contours of the French elites (Bourdieu 1989; Denord et LagneauYmonet 2016).

If the existence of elite institutions is obviously not unique to France, the specificity of the French context is partly due to the narrowness of recruitment of the "grandes écoles"; and secondly to the kind of legitimacy they confer. Scoring

\footnotetext{
A.-C. Wagner $(\bowtie)$

University of Paris I Panthéon-Sorbonne, Paris, France 
modes, academic selectivity, and the principle of the anonymous "concours" tend to give educational capital a central place in legitimating social domination (Gérard and Wagner 2015). What are the effects of globalization on this educational model? How does it change the content of legitimate cultural capital?

First, we discuss how inquiries into international schools help identify the specific features of the cultural and academic capital at stake in these reproductive strategies. These studies nevertheless make sense only if we try to situate international diplomas or international training in school hierarchies. This leads us to move to the issue of criteria for legitimizing elite institutions. Finally, we will show that the main difficulty is in assessing the conditions for mobilizing this capital in order to access leading positions.

\section{The Institutionalization of an International Capital: Studying International School Socialization}

We must guard against the illusion that elite cosmopolitanism is a radical novelty. Language skills, knowledge of several countries, familiarity with travel and ease in relations with foreigners are longstanding attributes of the upper classes. A fraction of the aristocracy and high bourgeoisie foster a family cosmopolitanism, consolidated from generation to generation and combining economic solidarity and family ties. In high society, the education of children traditionally includes an opening onto the world (Pinçon and Pinçon Charlot 2016; Wagner 2007).

The specificity of the more recent period lies in the institutionalization of these skills. International schools, originally founded for the children of high ranking civil servants working for international organizations, expanded in the 1960s as a consequence of the growing number of expatriates from the private sector. In 1968, an International Baccalaureate Programme was established by a private foundation in Geneva, "to provide students with a balanced education, to facilitate geographic and cultural mobility and to promote international understanding". Today, the International Baccalaureate Organization works with nearly 2000 schools in 150 countries and offers its programmes to more than one million pupils. In France, since 1981, an international option of the baccalaureate, prepared in international schools or in French schools abroad, validates a curriculum where literature, geography or history are taught in foreign languages by teachers from a partner country.

The methods used to analyze these forms of socialization need to be adjusted to the specificities of these programs. While school reproductive strategies are usually studied in a national context, these schools are located in a separate space, where languages, curricula and cultures of different countries compete. Curriculum studies necessarily include a geopolitical dimension. For instance, Dugonjic (2014) shows how World History and World Literature programs of the International Baccalaureate reproduce domination between nations and colonial relations. Nevertheless, it is difficult to identify a set of knowledge that would objectify the content of an 
international culture of elites. The schools are quite free to choose their own teaching and pedagogical methods, and generally provide a large number of options to fit the heterogeneity of national and academic backgrounds of pupils. The specific features of an international school culture are less likely to be found in curricula than in the process of socialization (Wagner 1998). International schools have, indeed, the major characteristic of being explicitly organized by reference to a public defined by highly exclusionary social properties: they enroll children of expatriates or diplomats, binational families and a small fraction of the local bourgeoisie seeking distinctive programs. Almost regardless of their curricula, the distinctiveness of such schooling, compared to other languages training programmes, lies in its recruitment. It consolidates cosmopolitan habitus, leading students to consider geographic mobility, the transition from one language to another, and relations with foreigners as natural. These schools put a special emphasis on personal accomplishments and socializing, with many parallel activities. So, scholars give great attention to the observation of classroom activities and interactions between students from different countries to identify specific forms of socialization. Interviews with managers and teachers and an analysis of internal literature are also used to shed light on the ethical and political dimensions of the discourses promoting peace and understanding (Bertron 2015).

International schools for international children are an exemplary case of social and educational valorization of a lifestyle. Because this teaching is only effective on students' distinctive lifestyles, it promotes a very essentialist vision of "international identity" and it is based on a distancing of academic skills.

This segment of the educational systems allows us to objectify the cultural and social resources that define an international capital. Yet the analysis of educational content or socialization processes gives no indication of the value of these resources. If these schools enroll children of various nationalities and claim to form international identities, the diplomas which they have prepared have a value that varies depending on national circumstances. International schools are the road to access the elites in some countries (Nogueira and Aguiar 2008; Panayotopoulos 2000; Niane 1992; Weenink 2007), but they have a very marginal position in the French educational system. We should mobilize other instruments to measure the educational value of international capital.

\section{The Internationalization of Legitimation Instances of Elite Training}

Are we witnessing a transformation of the school hierarchy criteria in favour of international know-how and competencies? In the French system, international diplomas have an ambiguous status. International culture certainly provides distinction that benefits the dominant classes, but it does not mean recognition of international schooling or foreign degrees. The International Baccalaureate is not 
recognized by the French state, and the international option of the French baccalaureate gives no advantage in the competition to access the best preparatory schools and "grandes écoles".

In higher education, in the same way, "international" programs, found mainly in the area of business and management, have long been a part of school products that offer a "refuge" to higher social origin students with poor academic results (Bourdieu 1989). The term "international" refers to diverse practices: some schools offer tuition in English, others organize internships and study abroad periods, some issue double degrees with institutions in other countries, others recruit foreign teachers or students abroad. "International" is not a well-defined program, which would hierarchize institutions. In fact, scholars studying elites have for a long time lost interest in these institutions, considered second-tier schools in the field of "grandes écoles".

However, since the 1990s, in France as in most industrialized countries, there has been a proliferation of business schools and a re-evaluation of their academic status, with an increase in the legitimacy of these programs and higher academic entry requirements (Blanchard 2009; Khurana 2007). How can we assess the changes in the relative value of these formations and the effects of internationalization of this area? The MBA is an American degree, but this is probably the diploma that can be considered closest to an international title due to its exponential expansion outside the United States, the cosmopolitan recruitment of major business schools, and international accreditation procedures. The Association to Advance Collegiate schools of Business (AACSB), which has accredited American institutions since 1916, expanded its geographical range in the 1990s to evaluate programs outside the United States. The European Foundation for Management Development (EFMD), based in Brussels since 1997, delivers the EQUIS (European Quality Improvement System) certification, while the UK-based Association of MBA accredits MBA and Master's degrees in more than 80 countries. Management programs are, moreover, subject to rankings with high exposure in the business press, notably The Economist, Business Week, The Wall Street Journal and the Financial Times. Linda Wedlin (2006) shows that these rankings that accompany the exponential development of management journals also challenge the competition between press titles. They contribute to the formation of an international field of management programs, with new original criteria.

Thus, whereas in France academic excellence has long been synonymous with state accreditation, we are witnessing the rise of new principles of legitimation, claiming their independence from national education systems. The "academic" selectivity of applicants in business schools is not measured by their previous academic achievement, but by international tests: the scores on the GMAT (Graduate Management Admissions Test) are intended to allow a comparison of the "skills" possessed by candidates all over the world, regardless of their disciplinary or national background.

The study of the criteria that make "international" excellence could thus provide clues to analyze the content of an international institutionalized capital. The accreditation organizations merge, on the one hand, academic criteria on the model of the most established disciplines and, on the other, market criteria based on careers and 
output wages of alumni. Academization is inseparable from commercialization in this area, with increased market competition for recruiting students, teachers, and for selling training services to businesses (Wagner 2015).

These assessments and international rankings have an effect on major French "grandes écoles", even outside of the management area. If international programs were at first mostly offered by second-tier private schools, with a proliferation of internships and study abroad cycles, participation in international networks now also concerns the most prestigious institutions (Lazuech 1999). Studies of internationalization strategies of French elite institutions (Delespierre 2015; Van Zanten 2018; Schliping 2018) show how the very French model of the "grandes écoles" has adapted to the new situation produced by the international competition between Higher Education systems. French students are selected by relatively unchanged national "concours", but most "grandes écoles" have developed, in parallel, new admission procedures, English-speaking pathways, and international degrees in order to attract an international audience.

This movement could attest to an evolution of the national definition of academic excellence for the benefit of new international standards, which goes with the transformation of legitimate cultural resources for the benefit of international expertise and competencies at the expense of the more highbrow cultural capital (Serre and Wagner 2015; Coulangeon 2011).

\section{Uses of International Capital for the Accession to Elite Positions}

The analysis of "institutionalized" international capital cannot be limited to the conditions of its production and that of its academic position; it requires research on the conditions of its effectiveness for the accession to the ruling classes. Two types of research can contribute to the latter: we can study the school trajectories of the members of the elite in order to identify those who have had international training; or we can seek to trace the careers of former students of international institutions. The first path led to several investigations in France. Studies into the recruitment of the greatest CEOs (Hartmann 2018; Dudouet and Grémont 2010) and research on a wider population, that of the persons in the Who's Who, (Denord et al. 2011) converge to show the still prominent position of national "grandes écoles" in the training of the elite, albeit with a rise of business schools. Studies abroad or international diplomas remain relatively infrequent among the leaders' educational paths, although their share increases with time and they are more frequent when you leave the ruling elite and look at all high executives.

The second type of research that involves the alumni of international institutions is more difficult to conduct, which shows the limits of the effects of this educational international capital. Data on alumni of various international schools are indeed often incomplete: the directories do not exist or are not up to date; the alumni 
associations are not very active. These shortcomings are indicative of a fragility of international capital. Networks seem difficult to mobilize internationally. Thus, a survey of Mexican students in French business schools shows that the majority of alumni interviewed gained very little benefit from their degree. Attending French business schools, even the top-ranked ones in international ranking, does not seem to guarantee career benefits outside the country (Garcia-Garza and Wagner 2018). The French business schools have opened to foreigners, but it seems that the social and symbolic capitals that they give remain largely reserved to nationals: national and social boundaries remain extremely present in the distribution of capital.

This calls for further reflection on the conditions for mobilizing international capital. The recruitment of students of different nationalities does not mechanically produce international networking. International capital, like all forms of social capital, is based on prior group cohesion, cemented by similarities in habitus and objective interests, and it assumes an active and ongoing work to be maintained and managed (Bourdieu 1980). This is probably one of the limits of international elite institutions. Sharing a classroom during preparation for a master or MBA is not enough to create an "esprit de corps" and the dispositions that are necessary to maintain it. The establishment and management of an international social capital are based on socially selective properties, directly correlated to the family heritage: agents who are already enrolled in a family international culture are the most adjusted to the constraints associated with the management of international capital (Börjesson and Broady 2016).

Various researches on international schools and institutions in the French case highlight the obstacles to the primitive accumulation of international capital. This is a case which calls for further reflection on the articulation between the different states; incorporated, objectified and institutionalized cultural capital (Bourdieu 1979). If cultural capital in its institutionalized state is always dependent on inherited cultural capital - as evidenced by the fairly universal correlation between social origins and school success- this link is even stronger in the case of international schooling. This is due to the lability of educational content in "international" training and to the social conditions of these educations. International tuition is only effective on students who are already socially selected by their international properties. International educational projects, whether for young children or managers, have in common a focus on the social dimension of school rather than their vocation, in terms of skills and relational networks rather than of academic knowledge. In addition, the acquisition of international cultural capital is much more dependent on economic capital than other cultural acquisitions because of the cost of private schooling and of experiences from abroad that it presupposes.

It seems as well that international capital has to be regarded less as a capital that produces effects by itself than as a multiplier of initial resources. In the field of education, international routes may strengthen the position of those who have already acquired capital, including in their national-space, but they do not open pathways to leading positions. Difficulties in isolating the specific effects of international educational capital reveal the limits of the institutionalization of this resource, inherited in the family. 


\section{References}

Bertron, C. (2015). Savoir donner : les enjeux d'une définition scolaire de la philanthropie dans les pensionnats internationaux de Suisse romande. Cahiers de Recherche sur l'Education et les Savoirs, 14, 95-118.

Blanchard, M. (2009). From 'Ecoles Supérieures de commerce' to 'management schools': Transformations and continuity in French business schools. European Journal of Education, 44(4), 586-604.

Börjesson, M., \& Broady, D. (2016). Elite strategies in a unified system of higher education. The case of Sweden. L'Année sociologique, 66, 115-146.

Bourdieu, P. (1979). Les trois états du capital culturel. Actes de la recherche en sciences sociales, 30, 3-6.

Bourdieu, P. (1980). Le capital social. Notes provisoires. Actes de la recherche en sciences sociales, 31, 3-9.

Bourdieu, P. (1998 [1989]). The state nobility: Elite schools in the field of power (L. Clough, Trans.). Stanford: Stanford University Press.

Coulangeon, P. (2011). Les métamorphoses de la distinction. Paris: Grasset.

Delespierre, A. (2015). Des entreprises dans les salles de classe? La révolution conservatrice des grandes écoles d'ingénieurs. Cahiers de Recherche sur l'Education et les Savoirs, 14, 69-92.

Denord, F., \& Lagneau-Ymonet, P. (2016). Le concert des puissants. Paris: Raisons d'Agir.

Denord, F., Lagneau-Ymonet, P., \& Thine, S. (2011). Le champ du pouvoir en France. Actes de la recherche en sciences sociales, 190, 24-57.

Dudouet, F.-X., \& Grémont, E. (2010). Les Grands patrons en France. Du capitalisme d'État à la financiarisation. Paris: Lignes de Repères.

Dugonjic, L. (2014). Les IB Schools, une internationale élitiste. Emergement d'un espace mondial d'enseignement secondaire au XXè siècle. Dissertation. Paris: EHESS.

Garcia-Garza, D., \& Wagner, A.-C. (2018). "The internationalization of business 'knowledge' French business schools: Opening possibilities for Mexican elites?" in Agnès van Zanten (ed.), Elites in Education. Vol.2, London, Routledge, "Major Themes in Education", 2018, p. 141-162.

Gérard, E., \& Wagner, A.-C. (2015). Élites au Nord, élites au Sud: des savoirs en concurrence? Cahiers de la recherche sur l'éducation et les savoirs, 14, 7-26.

Hartmann, M. (2018). The international business elite: Fact of fiction? In O. Korsnes et al. (Eds.), New directions in elite studies. London: Routledge.

Khurana, R. (2007). From higher aims to hired hands. The social transformation of American Business schools and the unfilled promise of management as a profession. Princeton: Princeton University Press.

Lazuech, G. (1999). L'exception française. Le modèle des grandes écoles à l'épreuve de la mondialisation. Rennes: Presses Universitaires de Rennes.

Maxwell, C., et al. (Eds.). (2018). Elite education and internationalisation. From the early years to higher education. Basingstoke: Palgrave Macmillan.

Niane, B. (1992). Le transnational, signe d'excellence. Le processus de disqualification de l'Etat sénégalais dans la formation des cadres. Actes de la recherche en sciences sociales, 95, 13-25.

Nogueira, M.-A., \& Aguiar, A. (2008). La formation des élites et l'internationalisation des études: peut-on parler d'une 'bonne volonté internationale'? Éducation et sociétés, 21, 105-119.

Panayatopoulos, N. (2000). Une école pour les 'citoyens grecs du monde': les enjeux nationaux de l'international (avec la collaboration de Panos Georgiou). Regards Sociologiques, 19, 29-55.

Pinçon, M., \& Pinçon-Charlot, M. (2016). Sociologie de la bourgeoisie, La Découverte, « Repères ».

Schliping, S. A. (2018). Institutional Habitus of French Elite Colleges in the context of internationalisation: An in-depth look at the Écoles Normales Supérieures. In C. Maxwell et al. (Eds.), Elite education and internationalisation. From the early years to higher education. Basingstoke: Palgrave Macmillan. 
Serre, D., \& Wagner, A.-C. (2015). For a relational approach to cultural capital: A concept tested by changes in the French social space. The Sociological Review, 63, 433-450.

van Zanten, A. (Ed.). (2018). Elites in education. London: Routledge.

van Zanten, A., \& Darchy-Koechlin, B. (Eds.). (2015). Elites, privilege and excellence: The national and global redefinition of educational advantage. London/New York: Routledge.

Wagner, A.-C. (1998). Les nouvelles élites de la mondialisation. Une immigration dorée en France. Paris: Presses Universitaires de France.

Wagner, A.-C. (2007). La place du voyage dans la formation des élites. Actes de la recherche en sciences sociales, $170,58-65$.

Wagner, A.-C. (2015). La diffusion internationale des MBA. Vers un renouvellement des formes de légitimation de la domination économique. Social Sciences, Annual Trilingual Review of Social Research, 6, 144-152.

Wedlin, L. (2006). Ranking business schools. Forming fields, identities and boundaries in international management education. Cheltenham: Edward Elgar Publishing.

Weenink, D. (2007). Cosmopolitan and Established Resources of Power in the Education Arena, International Sociology 22(4): 492-516.

Open Access This chapter is licensed under the terms of the Creative Commons Attribution 4.0 International License (http://creativecommons.org/licenses/by/4.0/), which permits use, sharing, adaptation, distribution and reproduction in any medium or format, as long as you give appropriate credit to the original author(s) and the source, provide a link to the Creative Commons license and indicate if changes were made.

The images or other third party material in this chapter are included in the chapter's Creative Commons license, unless indicated otherwise in a credit line to the material. If material is not included in the chapter's Creative Commons license and your intended use is not permitted by statutory regulation or exceeds the permitted use, you will need to obtain permission directly from the copyright holder.

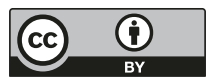

